\title{
Digital Transformation of Agricultural Production: Regional Aspect
}

\section{Aleksandr V. NEMCHENKO}

Ph.D. (in Economic Sciences)

Associate Professor

Department of Economic Security

Faculty of Economics

Volgograd State Agrarian University

26, Universitetskiy Av., Volgograd, 400002, Russia

\section{Tatyana A. DUGINA}

Ph.D. (in Economic Sciences)

Associate Professor

Department of Economic Security

Faculty of Economics

Volgograd State Agrarian University

26, Universitetskiy Av., Volgograd, 400002, Russia

\section{Evgeniy A. LIKHOLETOV}

Ph.D. (in Agricultural Sciences)

Associate Professor

Department of Economic Security

Faculty of Economics

Volgograd State Agrarian University

26, Universitetskiy Av., Volgograd, 400002, Russia

\section{Svetlana Y.SHALDOKHINA}

Ph.D. (in Economic Sciences)

Associate Professor

Department of Economic Security

Faculty of Economics

Volgograd State Agrarian University

26, Universitetskiy Av., Volgograd, 400002, Russia 


\title{
Alexandr A. LIKHOLETOV
}

Ph.D. (in Law Sciences)

\section{Associate Professor}

Department of Criminal Law of the Educational and Scientific Complex

for the Preliminary Investigation in the Department of Internal Affairs

Volgograd Academy of the Ministry of Internal Affairs of Russia

130, Istiricheskaya Str., Volgograd, 400089, Russia

\begin{abstract}
The article substantiates the objective inevitability of agriculture digital transformation. At the same time, the main goal of the digital technology introduction is defined as ensuring food security and achieving competitive advantages in the domestic and foreign markets of agricultural production.

In the process of the study, there were established three main components that provide the digital transformation of the agricultural sector - resource, internal and productive. An assessment of each of them in the conditions of agriculture of the Volgograd region was carried out, which made it possible to identify a number of difficulties hindering the active introduction of digital technologies. Among the main constraints is the lack of specific facts that can confirm the creation of conditions for the growth of the effective component of digital transformation, which could be a driver for the use of digital technologies by the agribusiness. Other equally important factors include the impossibility of the region's existing infrastructure to directly affect the internal component of the digital transformation of agricultural production, the low share of agricultural employees with a high level of digital literacy, as well as the lack of information technology specialists with additional knowledge of agricultural features.
\end{abstract}

Keywords: digital transformation; digital economy; agricultural production; region.

\section{Introduction}

In 2017, at the St. Petersburg International Economic Forum, Russian President Vladimir Putin noted that the digital economy will create fundamental conditions for the reform of all business processes throughout the country and will have a direct or indirect impact on every enterprise and citizen. Currently, the attention of the country's leadership, leading economists, business representatives and various sectors of the national economy is focused on organizing the process of formation and development of a digital economy in the country (Pradhan, Mukherjee, 2018). In recent months, this process has become even more urgent in connection with the emergence of a pandemic of the coronavirus infection COVID-19, the main way to combat which is self-isolation and maximum activation of remote (remote) methods of work. It is this opportunity that the digital 
transformation of economic processes can provide to a greater extent. Nevertheless, the main goal of the introduction of digital technologies continues to be the formation of competitive advantages in the domestic and foreign markets and the provision of food and economic security of the country on their basis. In this regard, the importance of the development of competitive types of industries is growing, which, given the missed opportunities of the innovative and breakthrough development path, puts the digitalization of the economy in the rank of priority tasks.

At the present stage, the agricultural sector is acquiring features that are characterized by the presence of a large and intensive flow of information (Sung, 2018; Tian et al., 2018). A huge stream of data comes from various sensors and devices located in the field and on the farm, from meteorological stations, satellites, contractors and is accumulated in the information centers of the participants in the production chain. This mechanism for collecting and processing information makes it possible:

1. to create information resources of a fundamentally new quality;

2. to determine a larger number of patterns and relationships between economic phenomena and technological processes;

3. to use various scientific methods for processing the obtained and systematized information base and make adequate decisions based on them that can minimize risks, as well as can improve the results of the final manufacturer.

Business units are using mobile or online applications that are capable of issuing recommendations and the necessary sequence of production operations, taking into account the analysis of many historical and current factors, both within the boundaries of a particular business entity and the entire technological chain, from the producer to the consumer of agricultural products (Nemchenko et al., 2019). Undoubtedly, for a more efficient and large-scale digital transformation, it is necessary to have sufficient resource capabilities. This potential should not be limited only to existing or developing research projects in the field of information technology, but to cover a wider range of factors, such as human resources, the ability and willingness of agricultural enterprises to introduce and apply digital technologies in their business activities, government support and etc.

\section{Methods}

The transition to the digital economy of both the agricultural sector and the entire national economy requires an understanding of the upcoming global changes not only in the design of information systems that are the essence of the digital economy, but also in the technical and technological processes that ensure the industry functioning. In this regard, an objective assessment of the 
potential for digital modernization of agriculture is necessary; for its implementation, a number of studies by domestic and foreign authors on the digital economy, statistics from the federal and regional levels, reports from relevant ministries and departments, data from specific agricultural producers of the Volgograd Region were used.

The process of processing the collected material and information included graphic, statistical, and also comparative methods.

\section{Results}

The world concept of modern agricultural production is based on the trajectory of economic trends, capturing in the third millennium a new quality of economic growth - the digital transformation of production. This methodological approach to the formation of modern national agriculture should be associated with the digitalization of the economy, ensuring the achievement of competitive advantages and determining the change of technological structures as the main element characterizing the economic structure of production (Korobeynikova et al., 2018). At the same time, the basic components of digital transformation should serve as the basis for the development and integration of this type of economy in all aspects of the functioning of agricultural production.

Within the boundaries of this study, there were proposed to distinguish three main components that ensure the digital transformation of agricultural production - resource, internal and productive (Figure 1).

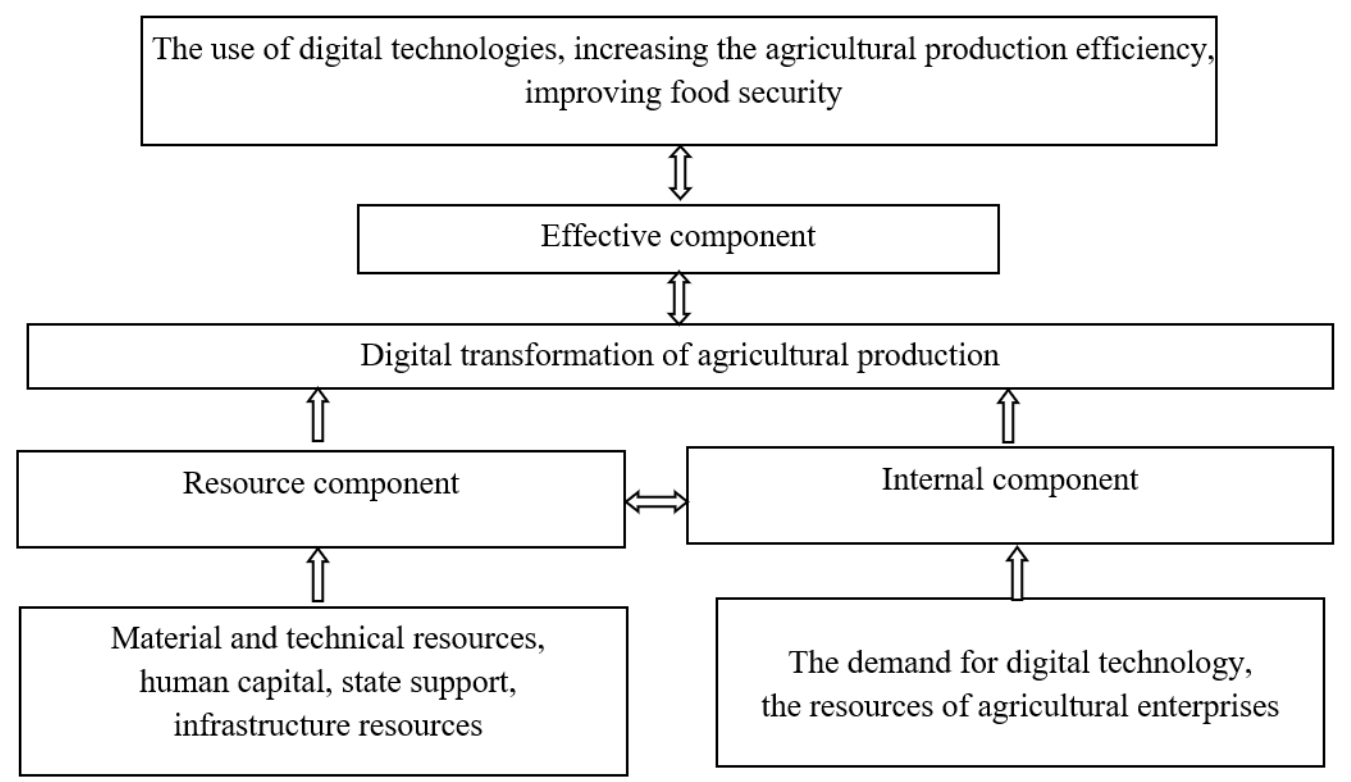

Figure 1. Components of the digital transformation of agricultural production

The resource component of the digital transformation of agricultural production includes the material and technical basis, human capital, state support, infrastructure. It is known that any 
production is preceded either by the evolutionary formation of the material and technical base, or rapid technological progress, or their combination, the latter being the most probable (Basso, Antle, 2020; Mardon, Belk, 2018). Consequently, in its development, the material and technical base goes through certain stages, that are characterized by technical and technological level. Each of them is individual and functionally connected with the previous one. In economics, these stages are called technological structures as a set of processes interfaced by the production principle, combined into a stable integrity and determining the reproduction cycle (Park et al., 2020).

Without dwelling on the chronology and characterization of technological levels, the study state that in the domestic economic literature there are currently two points of view regarding the emergence of a new technological structure based on the use of nanotechnologies in agriculture, which predetermine the accelerated development of molecular biology, genetic engineering, a qualitative change in the processes of cultivation of fundamentally new varieties of crops, the use of biotechnology, stem cells in the treatment and creation of new animal breeds (Guy, 2019). The second approach, which is more promising, is based on the introduction of digital technologies. In this case, the focus is on information resources that can be obtained from various sources - from sensors on machines and sowing complexes to data from the satellite and business partners (Rippa, Secundo, 2019).

For example, in the Volgograd region, approximately 2.1 thousand agricultural machines, including those provided with elements of modern digital technologies, were bought by agrarians for 6.5 billion rubles in 2018; 1190 units of which (including 161 tractors and 261 combines) cost 4.1 billion rubles. It was bought at the expense of state support. Systemic state support from federal and regional budgets made it possible to renew the fleet of agricultural machinery. In 2018, 63\% of combines and over $40 \%$ of tractors in the region had a service life of no more than 10 years, which sufficiently provides a strong foundation for the digital transformation of the agricultural sector of the region. According to the Ministry of Agriculture of Russia, the Volgograd region is one of the three leaders among the constituent entities of the Russian Federation in terms of the acquisition of new equipment, in total since 2014, the region's farms have acquired more than 10 thousand units of agricultural machinery, and its totaling cost was 25.5 billion rubles.

Another important part of the resource component is human capital. In the context of digital transformation, new business models are beginning to form adaptation and the functioning of which should be provided by human resources, consisting of competent employees of the business entity and the scientific community. 
In the Volgograd region, the number of employees engaged in research activities from 2001 to 2006 decreased from almost 5,000 to 4,000 people, but over the next two years there was an increase of more than 500 people. However, after this, the trend worsened significantly, namely, the number of personnel engaged in research and development from 2014 to 2018 decreased by 293 people (from 3,732 to 3,439 people). According to 2017 data, 191 people conducted research in the field of agriculture, of which 109 had an academic degree, while in 2013 there were 258 and 136 people, respectively. Negative dynamics is also observed in the training of scientific personnel, so if in 2014, 22 graduate students were accepted in the areas of training related to agriculture, then in 2017 their number was 14 people.

In 2018, 43 organizations were engaged in research and development, which is by 4 organizations less than in 2014, and one organization less than in 2017. These organizations include scientific, research, educational, research, design and technological institutes, research centers. In addition, 12 state universities and 6 branches of state universities, 5 licensed non-state universities and 11 branches, 6 academic research institutes and departments of the RAS are located in the region. The fact that funding for research was reduced led to significant decrease in the costs of science in 2017 - the costs of performing scientific research in 2013 were 9,640.5 million rubles, and in 2017 amounted to 3,917.9 million rubles (almost 2.5 times less). This change is mainly due to the absence of external costs (decreased from 4346.4 million rubles in 2013 to 370.2 million rubles in 2017). At the same time, it is gratifying to note an increase in the cost of basic research, which has grown almost 1.5 times from 271 million rubles in 2013 to 425.6 million rubles in 2017. At the same time, spending on applied research and scientific development decreased in total by 1445.8 million rubles.

A slightly different trend was noted directly in the agricultural sector of the region - in 2018, the total volume of state support for the agro-industrial complex reached an unprecedented level of 5,932 million rubles, which is $30 \%$ more than in 2017. Since 2014, the region has been conducting consistent activities related to efficient use funds, which allows annually increasing the volume of financing the industry. In 2018, the Volgograd Region was included in the top ten constituent entities of the Russian Federation in terms of bringing the federal budget funds to agricultural producers. The fundamental study of the justifications and the subsequent conclusion of nine agreements with the Ministry of Agriculture of Russia ensured an increase in the volume of state support for the agricultural sector in 2018 by almost 1370 million rubles, in comparison with the 2017 indicator farmers received funds for 13 types of subsidies, including 536.3 million rubles compensations to agribusiness affected by drought (Popova et al., 2018, p. 684-685). Also, in the region, as part of a double increase in export revenue, the project "Export of agricultural products" 
is being implemented as a part of the national project "International Cooperation and Export". To this end, a production program has been developed that can ensure the growth of the volume and quality of agricultural products, as well as the modernization of the transport and logistics infrastructure, within the digital transformation of the agricultural sector. Another area of state support is the departmental project "Digital Agriculture", the implementation of which began in the Volgograd region. The goal of this project is to ensure the digital transformation of agricultural production through the introduction of digital technologies and platform solutions to increase labor productivity in "digital" agricultural enterprises by 2 times by 2024 (Popova et al., 2017; Shkarlet et al., 2020).

The link between digital technologies and their implementation in practice is infrastructure. Foreign experience shows that the infrastructure for supporting digital transformation is a real tool for the positive influence of the authorities on regional economic development (Shepit'ko et al., 2015). This direction is provided through the implementation of the central information and analytical system of agriculture, as well as a unified federal information system of agricultural land. It should also be noted that on the basis of the data of the Agricultural Committee of the Volgograd Region in the region for several years, due to modern digital technologies, the turnover of land within the system "Agroportal" has been controlled. With the help of this project, information on crop areas and agricultural production is quickly and accurately collected. At this point in time, the task of introducing agrology technology is being solved. The purpose of this development is to create a digital base that would provide information support for the entire chain "from field to port" and enable agribusiness to minimize delivery costs, increase export profits from the sale of agricultural products (Spahn, 2020).

Regarding the internal and productive components, it should be noted that the region is actively implementing the technology of "precision farming" in economic activity (Serebryakova, 2019). The work aimed at digitalizing land management and planning for growing crops, which accompanies the process from sowing to direct cultivation right up to the exact determination of the type of fertilizer and the timing of their application, does not stop, and the state of crops is estimated based on aerial survey data (Ivanov et al., 2019). In 2019, it follows from the report of the Volgograd Region Agriculture Committee that about 150 enterprises on an area of about 600 thousand hectares already use similar technologies and this allows these business entities preventing effectively plant diseases, increasing crop yields, and receiving additional profit. In 2020, farmers are already talking about the use of unmanned aerial vehicles for these purposes. Nevertheless, the digital transformation of agricultural production cannot give instant results and, as a rule, is 
associated with high costs (Korobeynikova et al., 2017; Nemchenko et al., 2016). In this regard, we cannot talk about improving the efficiency of agriculture (Table 1).

Table 1. Performance indicators of agricultural enterprises of the Volgograd region for 20122018

\begin{tabular}{lccccccc}
\multicolumn{1}{c}{ Indicators } & $\mathbf{2 0 1 2}$ & $\mathbf{2 0 1 3}$ & $\mathbf{2 0 1 4}$ & $\mathbf{2 0 1 5}$ & $\mathbf{2 0 1 6}$ & $\mathbf{2 0 1 7}$ & $\mathbf{2 0 1 8}$ \\
\hline Profit, thousand rubles & 6052594 & 3782951 & 9555684 & 12808104 & 13595344 & 11929360 & 12223168 \\
\hline Total profitability, \% & 30.36 & 18.00 & 34.47 & 41.57 & 41.10 & 31.03 & 29.25 \\
\hline Profit margin, \% & 23.29 & 15.26 & 25.63 & 29.36 & 29.13 & 23.68 & 22.63 \\
\hline Return on equity, \% & 19.19 & 10.12 & 21.42 & 24.90 & 23.37 & 16.75 & 15.19
\end{tabular}

Thus, during the period from 2012 to 2018, there is no pronounced dynamics of the growth of the functioning efficiency of agricultural production in the region; its peak falls on 2015-2016 (when the prospects for digitalization were just beginning to appear), and already in 2017, the recession began. However, with regard to production volumes, their increase is noted here, especially for such types of products as vegetables, sunflower, milk and wool (Table 2).

Table 2. Agricultural production in the Volgograd region for 2012-2018, thousand tons

\begin{tabular}{lccccccc}
\multicolumn{1}{c}{ Type of product } & $\mathbf{2 0 1 2}$ & $\mathbf{2 0 1 3}$ & $\mathbf{2 0 1 4}$ & $\mathbf{2 0 1 5}$ & $\mathbf{2 0 1 6}$ & $\mathbf{2 0 1 7}$ & $\mathbf{2 0 1 8}$ \\
\hline Cereal & 2422.7 & 3088.5 & 3913.8 & 2920.9 & 4524.4 & 5651.4 & 3706.8 \\
\hline Sunflower & 457.8 & 736.3 & 683.7 & 731.1 & 813.4 & 576.0 & 943.3 \\
\hline Potatoes & 401.1 & 400.1 & 399.7 & 428.3 & 415.7 & 227.0 & 218.4 \\
\hline Vegetables & 829.1 & 797.8 & 801.3 & 899.1 & 923.2 & 1079.3 & 1000.1 \\
\hline $\begin{array}{l}\text { Cattle and poultry } \\
\text { in slaughter weight }\end{array}$ & 145.6 & 142.5 & 152.8 & 146.9 & 142.6 & 158.3 & 149.0 \\
\hline Milk & 521.2 & 529.6 & 524.7 & 511.3 & 515.6 & 526.0 & 537.1 \\
\hline Eggs, mln. pcs. & 778.3 & 734.0 & 757.2 & 761.2 & 796.6 & 752.6 & 759.9 \\
\hline Wool, tons & 2036 & 2204 & 2375 & 2332 & 2242 & 2525 & 2422
\end{tabular}

The increase in agricultural production in the Volgograd region over the past seven years indicates the fact of increased food security and, as a result, the strengthening of the effective component of the digital transformation of agriculture in the region.

\section{Discussion}

An indisputable fact is the need for digital transformation of both the entire national economy, and agricultural production in particular. As it was established, the result of these changes can be significant economic transformations, for example, it is expected to increase labor productivity by 2 times in 4 years. For the conditions of the Volgograd region, it is planned to develop the already existing service "Agroportal", which collects information about the farmland of the region. This information resource will be a single base, starting with crop rotation and agricultural land, ending with data on the financial and economic situation of agribusiness and weather conditions. 
Another important area of digital transformation in the region is agro-export (Ivanov et al., 2019). It is supposed to collect all the information from the field to the port. Again, data from meteorologists, freight forwarders, and agricultural chemists will be included, and the goal of this project is to generate objective data on the production and delivery of agricultural products for export to create the optimal logistics and pricing policy.

However, a number of issues arise that are directly related to the profitability and expediency of participation of agricultural producers directly in digital transformation, as well as the reality of a twofold increase in labor productivity in such a short period of time. Only specific facts confirming the increase in the efficiency of agricultural production, improving food security through the use of digital technologies, can serve as a driver for the digital transformation of agribusiness. It is a real possibility of increasing production efficiency and, as a consequence of its competitiveness that will ensure a more complete use of the resource and internal components of the digital transformation of agriculture.

\section{Conclusion}

Thus, there are no other alternatives to digital transformation capable of transferring agricultural production to a different, higher organizational and economic level. However, there are a number of difficulties that impede the active introduction of digital technologies in agriculture. So, it should be noted that the current infrastructure of the region does not directly affect the internal component of the digital transformation of agricultural production.

The demand for digital technologies in the agricultural sector remains low, as there is a disproportion between their presence and actual implementation in practice. A small number of agricultural producers in the region have a strong resource potential, but, even having one, cannot effectively dispose of it. One of the key problems in this case is the lack of comprehensive research and methodological developments related to assessing the possibility of digital transformation and the efficient use of existing digital technologies. Nevertheless, by the number of organizations using digital technologies, by the level of costs for their implementation and use in the agricultural sector, the Volgograd region occupies one of the leading places. In addition, digital transformation must be ensured not only through technical re-equipment, but also through human capital. The global tasks set by the country's leadership regarding the digitalization of the economy require the digital literacy of the employees of the enterprise, which is still a problem in rural areas. At the same time, it is necessary to expand the training of information technology specialists with additional knowledge of agricultural features. 


\section{References}

Basso, B., Antle, J. (2020). Digital agriculture to design sustainable agricultural systems. Nature Sustainability, 3(4), 254-256. https://doi.org/10.1038/s41893-020-0510-0

Guy, J.S. (2019). Digital technology, digital culture and the metric/nonmetric distinction. Technological Forecasting and Social Change, 145, 55-61. https://doi.org/10.1016/j.techfore.2019.05.005

Ivanov V.V., Ovchinnikov A.S., Kupriyanova S.V. (2019). Methodology of sustainable development of the agro-industrial complex. Bulletin of the Lower Volga Agro-University Complex, 4(56), 15-25. (in Russian)

Ivanov, V.V., Ovchinnikov, A.S., Kochetkova, O.V. (2019). Conceptual foundations of the digital transformation of the agro-industrial complex of the Volgograd region. Bulletin of the Lower Volga Agro-University Complex, 2(54), 18-25. (in Russian)

Korobeynikova, O.M., Korobeynikov, D.A., Popova, L.V., Savina, O.V., Kamilova, R.S. (2017). The current state of the payment infrastructure and development of payment systems in Russia and the Volgograd region. Espacios, 38(62).

Korobeynikova, O.M., Korobeynikov, D.A., Popova, L.V. (2018). Scenarios of digital innovation of the payment market in Russia. Advances in Social Science, Education and Humanities Research, 240, 174-178. https://dx.doi.org/10.2991/sicni-18.2019.35

Mardon, R., Belk, R. (2018). Materializing digital collecting: an extended view of digital materiality. $\quad$ Marketing Theory, 543-570. http://dx.doi.org/10.1177/1470593118767725

Nemchenko, A.V., Dugina, T.A., Likholetov, E.A. (2019). Digitalization as a priority area of economic development of agricultural industry. Bulletin of the Altai Academy of Economics and Law, 4, 118-123. (in Russian)

Nemchenko, A.V., Dugina, T.A., Likholetov, E.A., Malofeev, A.V., Likholetov, A.A. (2016). Conditions for developing sustainable growth of region's agricultural industry. International Journal of Economics and Financial Issues, 6(2), 207-211.

Park, K.T., Lee, J., Noh, S.D., Kim, H.-J. (2020). Digital twin-based cyber physical production system architectural framework for personalized production. The International Journal of 
IV International Scientific and Practical Conference "Modern S\&T Equipments and Problems in Agriculture"

Advanced Manufacturing 1787-1810. https://doi.org/10.1007/s00170-019-04653-7

Popova, L.V., Balashova, N.N., Dugina, T.A., Gorshkova, N.V., Turgaeva, A.A. (2017). Ways of increasing innovative activity in the agrarian sphere as a basis of food security. Contributions to Economics, (9783319606958), 381-386.

Popova, L.V., Dugina, T.A., Panova, N.S., Dosova, A.G., Skiter, N.N. (2018). New forms of state support for the agro-industrial complex in the conditions of digital economy as a basis of food security provision. Advances in Intelligent Systems and Computing, 622, 681-687.

Pradhan, K.C., Mukherjee, S. (2018). Examining technical efficiency in Indian agricultural production using production frontier model. South Asia Economic Journal, 19(1), 22-42.

Rippa, P., Secundo, G. (2019). Digital academic entrepreneurship: the potential of digital technologies on academic entrepreneurship. Technological Forecasting and Social Change, $146,900-911$.

Serebryakova, M.F. (2019). Economic behavior of agricultural organizations in the face of uncertainty. Economics of agricultural and processing enterprises, 9, 31-34. (in Russian)

Shepit'ko, R.S., Dugina, T.A., Nemchenko, A.V., \& Likholetov, E.A. (2015). Multifactor vector of the agriculture development in the region. Economy of the region, 4(44), 275-288. (in Russian)

Shkarlet, S., Dubyna, M., Shtyrkhun, K., Verbivska, L. (2020). Transformation of the paradigm of the economic entities development in digital economy. WSEAS Transactions on Environment and Development, 16, 413-422.

Spahn, A. (2020). Digital objects, digital subjects and digital societies: deontology in the age of digitalization. Information (Switzerland), 11(4), 228.

Sung, W.J. (2018). The empirical study on digital literacy from the viewpoint of digital accessibility. International Journal of Engineering and Technology (UAE), 7(3.13), 137-140.

Tian, T., Whalen, J.K., Dutilleul, P. (2018). Agricultural practices for crop residue transformation into soil organic matter in cold humid temperate agroecosystems. CAB Reviews: Perspectives in Agriculture, Veterinary Science, Nutrition and Natural Resources, 13(060), 1-15. http://dx.doi.org/10.1079/PAVSNNR201813060 